\title{
Nitrogen Fixation by Gloeothece sp. PCC 6909: Respiration and Not Photosynthesis Supports Nitrogenase Activity in the Light
}

\author{
By PAUL S. MARYAN, ${ }^{1}$ ROBERT R. EADY, ${ }^{1}$ ALAN E. CHAPLIN ${ }^{2}$ AND \\ JOHN R. GALLON $2 *$ \\ ${ }^{1}$ AFRC Unit of Nitrogen Fixation, University of Sussex, Brighton BNI 9RQ,UK \\ ${ }^{2}$ Department of Biochemistry, University College of Swansea, Singleton Park, \\ Swansea SA2 8PP, UK
}

(Received 9 April 1985; revised 15 August 1985)

\begin{abstract}
Nitrogenase activity of suspensions of the unicellular cyanobacterium Gloeothece sp. PCC 6909 plotted against the concentration of dissolved $\mathrm{O}_{2}\left(\mathrm{dO}_{2}\right)$ resulted in a bell-shaped curve, both in the light and in the dark, with optima of 25 or $80 \mu \mathrm{M}-\mathrm{O}_{2}$ depending on the age of the culture. At the optimum $\mathrm{dO}_{2}$, nitrogenase activity [typically 4 to $6 \mathrm{nmol} \mathrm{C}_{2} \mathrm{H}_{4}(\mathrm{mg} \text { protein })^{-1} \mathrm{~min}^{-1}$ ] was similar in the light or in the dark. Alteration of light intensity from zero to $2 \mathrm{klx}$, or addition of 3-(3,4-dichlorophenyl)-1,1-dimethylurea (DCMU), had no effect on nitrogenase activity. At $1 \mathrm{klx}$ the ADP/ATP ratio was 0.2 and showed only a marginal increase as the $\mathrm{dO}_{2}$ was increased. However, a high level of illumination $(30 \mathrm{klx})$ stimulated or inhibited nitrogenase activity, depending on the external $\mathrm{dO}_{2}$, presumably as a consequence of changes in the intracellular $\mathrm{O}_{2}$ concentration; in the presence of DCMU, activity increased twofold, independent of $\mathrm{dO}_{2}$.

In the dark, the dependence of the rate of respiration on $\mathrm{O}_{2}$ concentration suggested the presence of three $\mathrm{O}_{2}$-uptake systems with apparent $K_{\mathrm{m}}$ values of $1 \mu \mathrm{M}, 5 \mu \mathrm{M}$ and $25 \mu \mathrm{M}$. The ADP/ATP ratio under anaerobic conditions was 0.47 and showed a marked decrease as $\mathrm{dO}_{2}$ was increased to $25 \mu \mathrm{M}$. A CN-insensitive respiratory activity, which neither supported nitrogenase activity nor was coupled to ATP synthesis, was associated with the system with the apparent $K_{\mathrm{m}}$ of $5 \mu \mathrm{M}$. The dependence of the specific activity of nitrogenase on $\mathrm{dO}_{2}$ indicated that both the high affinity $\left(K_{\mathrm{m}} 1 \mu \mathrm{M}\right)$ and low affinity $\left(K_{\mathrm{m}} 25 \mu \mathrm{M}\right) \mathrm{O}_{2}$-uptake systems contributed ATP or reductant for $\mathrm{N}_{2}$-fixation. $\mathrm{KCN}(2.5 \mathrm{mM})$ completely inhibited nitrogenase activity in the dark and at moderate levels of illumination and $\mathrm{dO}_{2}$. We conclude that respiration is the major source of reductant and ATP for nitrogenase activity both in the dark and in the light, but that photosystem I can contribute ATP at very high levels of illumination.
\end{abstract}

\section{INTRODUCTION}

To grow diazotrophically, cyanobacteria have to overcome the problem of the sensitivity of nitrogenase towards inactivation by both photoevolved and atmospheric $\mathrm{O}_{2}$. In many species of filamentous cyanobacteria protection is achieved by compartmentalization of nitrogenase into heterocysts (Stewart, 1980). Gloeothece is a unicellular cyanobacterium which fixes $\mathrm{N}_{2}$ aerobically but does not produce heterocysts. Cultures of Gloeothece grown under alternating periods of light and dark fix $\mathrm{N}_{2}$ only in the dark periods, at the expense of endogenous carbohydrate reserves accumulated in the preceding light period (Mullineaux et al., 1980, 1981). However, in cultures grown under continuous illumination, $\mathrm{N}_{2}$-fixation and oxygenic photosynthesis coexist within a single cell (Gallon et al., 1974).

Abbreviation: DCMU, 3-(3,4-dichlorophenyl)-1,1-dimethylurea. 
The questions arise (Gallon, 1980) whether, under constant illumination, respiration or photosynthesis provides the reductant and ATP necessary for nitrogenase function, and how nitrogenase is protected from inactivation by environmental and photosynthetically generated $\mathrm{O}_{2}$. This paper describes an investigation of the relationship between nitrogenase activity and different steady-states of dissolved $\mathrm{O}_{2}$ concentration $\left(\mathrm{dO}_{2}\right)$ in the light and in the dark. We have also determined the effect of $\mathrm{dO}_{2}$ on the respiratory rate of Gloeothece and the inhibitory effect of cyanide on respiration and nitrogenase activity.

\section{METHODS}

Organism and growth conditions. An axenic culture of Gloeothece sp. PC 6909 was a generous gift from Dr R. Rippka, Institut Pasteur, Paris, and was grown at $25^{\circ} \mathrm{C}$ under constant illumination (1 klx) in ASM-1 medium free of combined nitrogen (Gallon et al., 1978). Stock cultures were maintained on agar slopes of ASM-1 medium solidified with agar $(1 \%, w / v)$. Experimental cultures were either sparged or shaken under air. Checks for contamination were made by plating on ASM-1 and also by thorough microscopic examination.

Respiratory $\mathrm{O}_{2}$ consumption. Stationary phase cultures were concentrated to about $2 \mathrm{mg}$ protein $\mathrm{ml}^{-1}$ by centrifuging and resuspending in fresh medium before they were transferred to a vessel $(3 \mathrm{ml})$ fitted with a Clarktype $\mathrm{O}_{2}$ electrode (Rank Bros), previously calibrated at low $\mathrm{dO}_{2}$ by adding small volumes of $\mathrm{O}_{2}$-saturated medium. All tests were at $30^{\circ} \mathrm{C}$. After $30 \mathrm{~min}$ incubation in the dark under air with constant stirring, the vessel was sealed and the $\mathrm{O}_{2}$-uptake measured until the dissolved $\mathrm{O}_{2}$ was completely utilized. The curves of $\mathrm{O}_{2}$ concentration vs time were digitized using a Hewlett-Packard plotter type $7220 \mathrm{C}$ linked to a PDP1134A computer and converted to rates of $\mathrm{O}_{2}$ uptake vs $\mathrm{O}_{2}$ concentration curves by drawing tangents to the digitized data. The resulting curves were then smoothed using a cubic spline algorithm procedure. Typical results are shown in Fig. 4. Values of apparent $K_{\mathrm{m}}$ and $V_{\max }$ were calculated using the $S / v$ vs $S$ linear transform (Cornish-Bowden, 1979).

Extraction of nucleotides. A $4 \mathrm{ml}$ sample of culture (typical density between 20 and $35 \mu \mathrm{g}$ protein $\mathrm{ml}^{-1}$ ) was mixed with an equal volume of $20 \%(\mathrm{w} / \mathrm{v})$ trichloroacetic acid in $50 \%(\mathrm{v} / \mathrm{v})$ methanol. After $5 \mathrm{~min}$, the solution was neutralized by shaking with $20 \mathrm{ml}$ water-saturated ether, which was then removed, avoiding any water loss. This step was repeated three times. Final traces of ether were removed by placing the solution in a water bath at $50{ }^{\circ} \mathrm{C}$ for $5 \mathrm{~min}$. The neutralized suspension was then disrupted in a French pressure cell at $69 \mathrm{MPa}$ before centrifugation $\left(10000 \mathrm{~g}\right.$ for $10 \mathrm{~min}$ at $\left.4^{\circ} \mathrm{C}\right)$ to remove cell debris. The supernatant was collected and $1.5 \mathrm{ml} 1 \mathrm{M}$ Tris/ $\mathrm{HCl}$ buffer, $\mathrm{pH} 7 \cdot 4$, added before removing $5 \times 1 \mathrm{ml}$ samples for freeze-drying overnight.

Measurement of ATP and ADP. The freeze-dried extracts were redissolved in $0.5 \mathrm{ml}$ water. For measurement of ADP, conversion mixture $(50 \mu \mathrm{l})$, containing $50 \mu \mathrm{mol} \mathrm{KCl}, 6 \mu \mathrm{mol} \mathrm{MgCl}_{2}$ and $0.125 \mu$ kat pyruvate kinase, was added and the mixture left for $45 \mathrm{~min}$ at room temperature. The reaction was then stopped by placing the tubes in a water bath at $90^{\circ} \mathrm{C}$ for $5 \mathrm{~min}$.

Crude luciferin/luciferase was extracted from $50 \mathrm{mg}$ dried firefly lanterns (Sigma), suspended in $5 \mathrm{ml}$ water. Insoluble material was removed by centrifugation $\left(18000 \mathrm{~g}\right.$ for $\left.10 \mathrm{~min}, 4^{\circ} \mathrm{C}\right)$. The supernatant was then activated by adding $120 \mathrm{mg}$ calcium phosphate and shaking gently at room temperature for $10 \mathrm{~min}$. The calcium phosphate was removed by centrifugation at $400 \mathrm{~g}$ for $10 \mathrm{~min}$ at $4^{\circ} \mathrm{C}$ and the procedure repeated. To ensure complete removal of the calcium phosphate, the final centrifugation step was done at $18000 \mathrm{~g}$ for $10 \mathrm{~min}$ at $4^{\circ} \mathrm{C}$. The pale yellow supernatant was removed and kept on ic: until required. It was stable for up to $6 \mathrm{~h}$.

ATP was assayed by adding a $50 \mu \mathrm{l}$ sample to $1 \mathrm{ml}$ assay medium $(0.02 \mathrm{M}$-glycylglycine buffer, $5 \mathrm{mM}$-sodium arsenate, $4 \mathrm{mM}-\mathrm{MgSO}_{4}, \mathrm{pH} 8.0$ ) in a bioluminescence tube, which was placed in a luminometer (LKB model 1250 or Berthold Biolumat LB9500). The background reading was taken before $0.1 \mathrm{ml}$ luciferin/luciferase was syringed manually into the tube via the injection port (zero time) and the $\mathrm{mV}$ output integrated over a pre-set $10 \mathrm{~s}$ counting period.

Bovine serum albumin was added to an ATP solution to a concentration of $25 \mu \mathrm{g} \mathrm{ml}^{-1}$. This solution was then subjected to the same extraction procedure as the samples. After freeze-drying, the standard ATP was reconstituted and used to construct a calibration curve over the range 0 to 20 pmol ATP.

ATP concentrations were measured directly on unconverted samples and ADP was determined by subtraction of the ATP value from that obtained after conversion of ADP to ATP.

Measurement of nitrogenase activity of cell suspen:ions. Activity was measured in the system described by Haaker et al. (1974) modified to exclude light other than that provided by Osram white-light fluorescent tubes illuminating the entire culture through a small window. A closed gas phase consisting of different partial pressures of $\mathrm{O}_{2}\left(\mathrm{pO}_{2}\right)$ in $\mathrm{N}_{2}$ was recycled through the culture by an air pump. Dissolved $\mathrm{O}_{2}$ was measured using a lead-silver electrode (Uniprobe) with a detection limit of $0.5 \mu \mathrm{M}-\mathrm{O}_{2}$. Samples of culture, typically $15-30 \mu \mathrm{g}$ protein $\mathrm{ml}^{-1}(24 \mathrm{ml})$ were placed in the thermostatted vessel at $30^{\circ} \mathrm{C}$ in the dark, and sparged with $\mathrm{N}_{2}$ until $\mathrm{dO}_{2}$ was zero. The required $\mathrm{dO}_{2}$ was imposed by introducing $\mathrm{O}_{2}$ in the $\mathrm{N}_{2}$ used to sparge the culture. The vessel was then sealed with a rubber closure and the culture exposed to the chosen light intensity. To start the assay, $\mathrm{C}_{2} \mathrm{H}_{2}(8.5 \%$,v/v) was injected into 

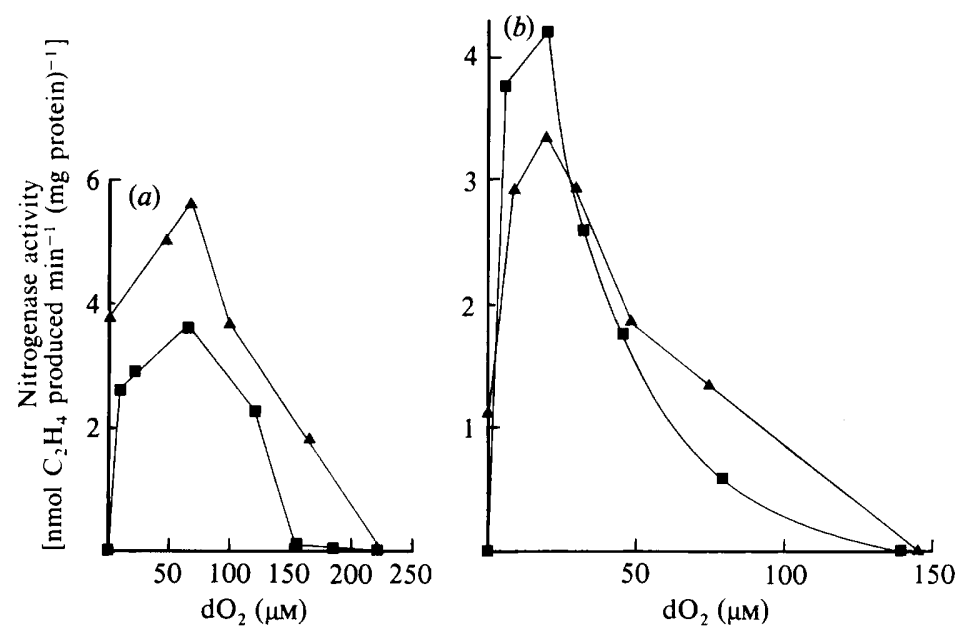

Fig. 1. Effect of $\mathrm{dO}_{2}$ on nitrogenase activity of $(a)$ stationary phase cultures ( $25 \mathrm{~d}$ old $)$ of Gloeothece $\mathrm{sp}$. PCC 6909 in the light at $2 \mathrm{klx}(\boldsymbol{\Delta})$ and in the dark $(\boldsymbol{\square})$, and $(b)$ exponential phase cultures ( $8 \mathrm{~d}$ old) in the light at $1 \mathrm{klx}(\boldsymbol{\Delta})$ and in the dark $(\boldsymbol{\square})$. As a consequence of day to day fluctuations in the specific activity of the cultures the activities obtained in the light and dark were different. However, for a sample from a given culture maintained at a given $\mathrm{dO}_{2}$ there was no effect on the rate of $\mathrm{C}_{2} \mathrm{H}_{2}$ reduction on changing the illumination from 0 to $2 \mathrm{klx}$ (Fig. 3). The rates of $\mathrm{C}_{2} \mathrm{H}_{2}$ reduction were determined at different $\mathrm{dO}_{2}$ over at least $30 \mathrm{~min}$ to establish that linear rates were maintained.

the gas headspace. At intervals, $0.5 \mathrm{ml}$ gas samples were removed by syringe to measure $\mathrm{C}_{2} \mathrm{H}_{4}$ by gas chromatography. The use of a $24 \mathrm{ml}$ culture volume compared with the $58 \mathrm{ml}$ total gas volume buffered the imposed $\mathrm{dO}_{2}$ from changes due to $\mathrm{O}_{2}$-uptake or photoevolution of $\mathrm{O}_{2}$. To obtain saturating light intensities a projector beam was used for illumination.

Measurement of protein content. Cultures were concentrated by centrifuging and protein was estimated by the Lowry method, modified by heating the samples at $100^{\circ} \mathrm{C}$ in the alkaline solution for $30 \mathrm{~min}$ before assay.

\section{RESULTS}

\section{Effect of $\mathrm{dO}_{2}$ on nitrogenase activity}

Nitrogenase activity in the dark. Under strictly anaerobic conditions no $\mathrm{C}_{2} \mathrm{H}_{2}$ reduction was observed over $2.5 \mathrm{~h}$. The effect of imposing increasing $\mathrm{dO}_{2}$ on nitrogenase activity is shown in Fig. $1(a)$. A rapid increase in activity was observed at $2 \mu \mathrm{M}-\mathrm{O}_{2}$ followed by a broad optimum, with a maximum rate [typically 4 to $6 \mathrm{nmol} \mathrm{C}_{2} \mathrm{H}_{4}(\mathrm{mg} \text { protein })^{-1} \mathrm{~min}^{-1}$ ] observed near $80 \mu \mathrm{M}$ $\mathrm{O}_{2}$. Activity was inhibited by higher $\mathrm{dO}_{2}$, declining very rapidly in the range 125 to $150 \mu \mathrm{M}$. This general pattern was observed consistently, but the optimum $\mathrm{dO}_{2}$ and the maximum specific activity varied with the age of the culture. Young cultures ( 2 to $12 \mathrm{~d}$ ) had lower optima of approx. $25 \mu \mathrm{M}-\mathrm{O}_{2}$ and were completely inhibited by $120 \mu \mathrm{M}-\mathrm{O}_{2}$ (Fig. $1 \mathrm{~b}$ ). For all cultures tested, time courses of nitrogenase activity at inhibitory $\mathrm{dO}_{2}$ values were linear over the $20 \mathrm{~min}$ assay period usually used, even at the highest $\mathrm{dO}_{2}$ tested.

Nitrogenase activity in the light. In the light, substantial rates of $\mathrm{C}_{2} \mathrm{H}_{2}$ reduction were observed in the absence of added $\mathrm{O}_{2}$. The rate depended on the light intensity, increasing over the range 0.5 to $2 \mathrm{klx}$ (Fig. 2). In contrast, when a positive $\mathrm{dO}_{2}$ was imposed, the rate of $\mathrm{C}_{2} \mathrm{H}_{2}$ reduction was independent of the light intensity up to $2 \mathrm{klx}$ (Fig. 3) and the pattern observed (Fig. $1 a, b$ ) with increasing $\mathrm{dO}_{2}$ was similar to that in the dark.

At these light intensities no increase in $\mathrm{dO}_{2}$ as a consequence of photosynthetic $\mathrm{O}_{2}$ evolution was detected during the $30 \mathrm{~min}$ over which measurements were made. At saturating light intensities $(\sim 30 \mathrm{klx})$, however, a small increase in $\mathrm{dO}_{2}$ occurred but the effect on nitrogenase activity depended on the initial $\mathrm{dO}_{2}$. Cultures with an optimum $\mathrm{dO}_{2}$ for activity of $25 \mu \mathrm{M}$, maintained at a sub-optimal $\mathrm{dO}_{2}(7 \cdot 2 \mu \mathrm{M})$, showed an increase in specific activity from 1.6 to 


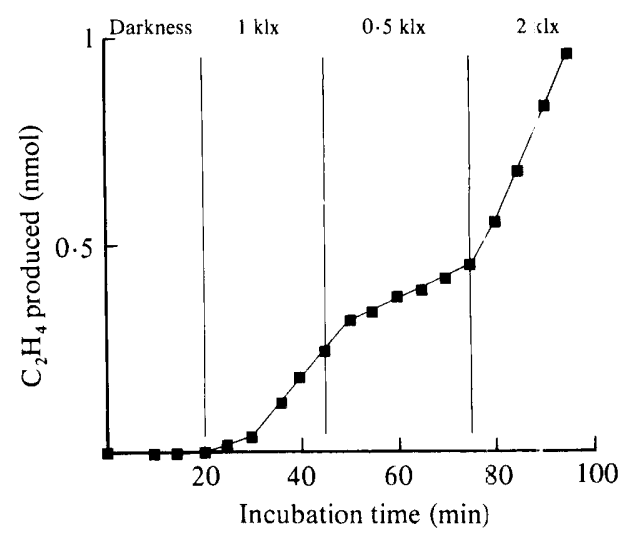

Fig. 2

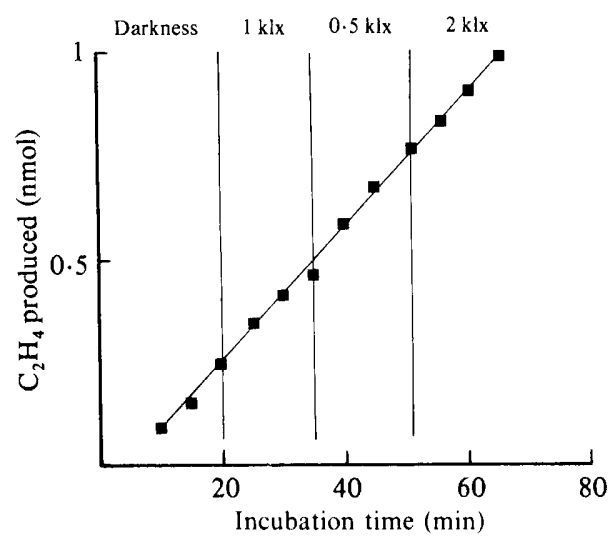

Fig. 3

Fig. 2. Effect of varying the light intensity on $\mathrm{C}_{2} \mathrm{H}_{2}$ reduction by a culture of Gloeothece sp. PCC 6909 maintained at zero external $\mathrm{dO}_{2}$. Results are from a single experiment but are typical.

Fig. 3. Effect of varying light intensities on $\mathrm{C}_{2} \mathrm{H}_{2}$ reduction by suspensions of Gloeothece sp. PCC 6909 maintained at a $\mathrm{dO}_{2}$ of $8 \mu \mathrm{M}$. Results are from a single experiment but are typical.

$2.7 \mathrm{nmol} \mathrm{C}_{2} \mathrm{H}_{4}$ produced $\min ^{-1}$ (mg protein) ${ }^{-1}$, whilst those maintained at a higher than optimal $\mathrm{dO}_{2}(82 \mu \mathrm{M})$ showed a decrease in activity from 0.5 to $0.35 \mathrm{nmol} \mathrm{C}_{2} \mathrm{H}_{4}$ produced $\mathrm{min}^{-1}$ $(\mathrm{mg} \text { protein })^{-1}$ compared with the rate observed at $2 \mathrm{klx}$.

When photosynthetic $\mathrm{O}_{2}$ evolution was inhibited with $10 \mu \mathrm{M}-\mathrm{DCMU}$, saturating light intensities stimulated nitrogenase activity twofold compared with the rate in the dark over the range 5 to $220 \mu \mathrm{M}-\mathrm{O}_{2}$. In contrast, illumination at $2 \mathrm{klx}$ had little effect on nitrogenase activity.

\section{Effect of $\mathrm{dO}_{2}$ on respiration}

$\mathrm{O}_{2}$-uptake by concentrated suspensiors of Gloeothece was measured in a closed system in the dark. The rate of respiration, measured continuously as the $\mathrm{dO}_{2}$ decreased from air saturation $(220 \mu \mathrm{M})$ to $0.5 \mu \mathrm{M}$, was non-linear, since the rate increased rapidly up to $30 \mu \mathrm{M}-\mathrm{O}_{2}$ and then increased more gradually up to $200 \mu \mathrm{M}$ (Fig. 4). The initial rapid increase was a complex response, suggesting the presence of two types of $\mathrm{O}_{2}$-uptake activity with different affinities for $\mathrm{O}_{2}$ (Fig. 4, inset). The data up to $30 \mu \mathrm{M}-()_{2}$ fit best to the sum of two hyperbolic concentrationactivity curves with approximate $K_{\mathrm{m}}$ values of $1 \mu \mathrm{M}$ - and $5 \mu \mathrm{M}-\mathrm{O}_{2}$, and $V_{\max }$ values of 1.32 and $2 \mu \mathrm{mol} \mathrm{min}$ m $^{-1}$ (mg protein) ${ }^{-1}$, respectively. The gradual increase at higher $\mathrm{dO}_{2}$ was associated with a lower affinity $\mathrm{O}_{2}$-uptake system with an apparent $K_{\mathrm{m}}$ of $25 \mu \mathrm{M}$, and a $V_{\max }$ of $2 \cdot 2 \mu \mathrm{mol}$ $\min ^{-1}(\mathrm{mg} \text { protein })^{-1}$. Similar data were obtained for cultures that showed optimum rates of nitrogenase activity at $25 \mu \mathrm{M}-$ or $80 \mu \mathrm{M}-\mathrm{O}_{2}$. The complex response of respiration rate as a function of $\mathrm{dO}_{2}$ is not due to exhaustion of reductant during the duration of the experiments (typically 20 to $40 \mathrm{~min}$ ) since the rate of $\mathrm{C}_{2} \mathrm{H}_{2}$ reduction was linear, at all $\mathrm{dO}_{2}$ tested, over this period. Comparison of Figs $1(a)$ and $1(b)$ with Fig. 4 indicates that, in the dark, nitrogenase activity increases over a range of $\mathrm{dO}_{2}$ where both the high and low affinity $\mathrm{O}_{2}$-uptake systems could function to provide ATP for nitrogenase activity (see also Fig. 6).

\section{Effect of $K C N$ on r'spiration and nitrogenase activity}

Respiration in the dark was inhibited $85 \%$ by $2.5 \mathrm{~mm}-\mathrm{KCN}$ but the residual $\mathrm{O}_{2}$-uptake rate was linear above $15 \mu \mathrm{M}-\mathrm{O}_{2}$ (Fig. 5). An analysis of the rate of $\mathrm{O}_{2}$-uptake as a function of $\mathrm{dO}_{2}$ below $15 \mu \mathrm{m}$ indicated that the $\mathrm{CN}^{-}$insensitive respiration was associated with the $\mathrm{O}_{2}$-uptake system with an apparent $K_{\mathrm{m}}$ of $5 \mu \mathrm{M}-\mathrm{O}_{2}$. In the dark, $\mathrm{KCN}$ totally inhibited $\mathrm{C}_{2} \mathrm{H}_{2}$ reduction over the range 10 to $120 \mu \mathrm{M}-\mathrm{O}_{2}$. This inhibition was not due to substrate competition between $\mathrm{C}_{2} \mathrm{H}_{2}$ and $\mathrm{CN}^{-}$for nitrogenase since no $\mathrm{CH}_{4}$ was detected. In the light, a more complex pattern was 


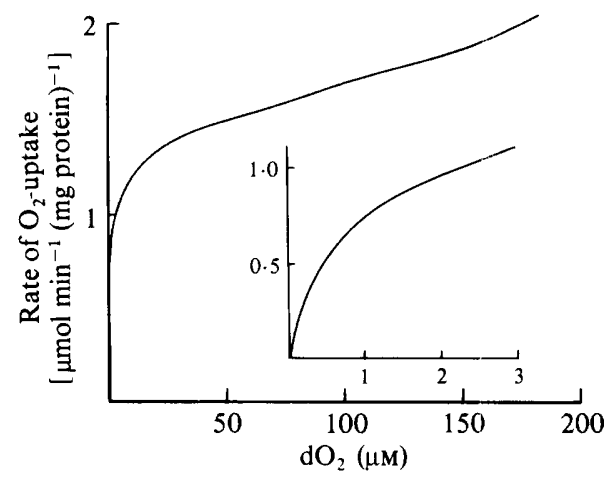

Fig. 4

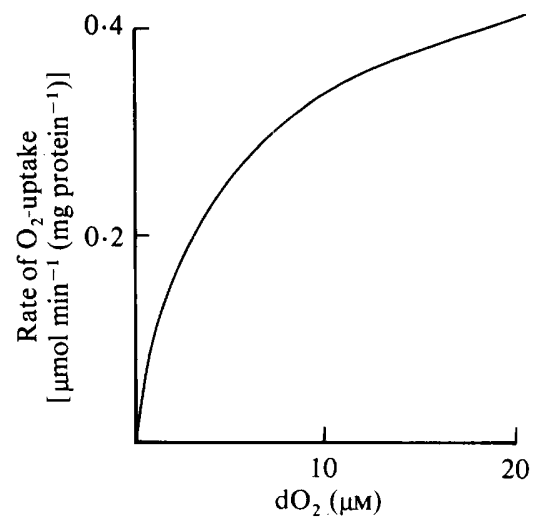

Fig. 5

Fig. 4. Computer-generated curves showing the rates of respiration as a function of $\mathrm{O}$, concentration by suspensions of Gloeothece sp. PCC 6909. A normal progress curve of $\mathrm{O}_{2}$-uptake at $30^{\circ} \mathrm{C}$ was digitized and tangents were drawn to the data to obtain rates. The curves obtained were then smoothed (see Methods for details). The inset shows the expanded scale used to analyse the initially rapid response to low $\mathrm{dO}_{2}$. Results are from a single experiment but are typical of $\mathrm{N}_{2}$-grown cultures.

Fig. 5. Computer-generated curve showing the rate of respiration as a function of $\mathrm{O}_{2}$ concentration by a suspension of Gloeothece sp. PCC 6909 in the presence of $2.5 \mathrm{~mm}-\mathrm{KCN}$. A typical progress curve of $\mathrm{O}_{2}$-uptake at $30^{\circ} \mathrm{C}$ was digitized and tangents were drawn to the data to obtain rates. The curve obtained was then smoothed (see Methods for details). Results are from a single experiment but are typical of $\mathrm{N}_{2}$-grown cultures.

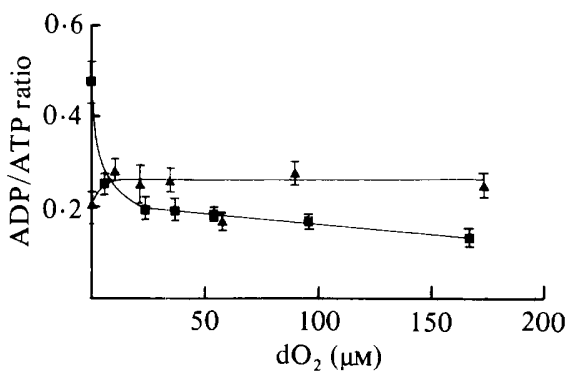

Fig. 6. Effect of $\mathrm{dO}_{2}$ on the ADP/ATP ratio in extracts of Gloeothece sp. PCC 6909 in the light at $1 \mathrm{klx}$ $(\boldsymbol{A})$ and in the dark ( $\boldsymbol{\square})$. Cultures were maintained at a fixed $\mathrm{dO}_{2}$ and samples $(4 \mathrm{ml})$ removed for nucleotide analysis as described in Methods. Each extract was divided into 5 samples $(1 \mathrm{ml})$ which were assayed in duplicate. The data shown are therefore the mean of 10 assays and the error bars show the standard deviation from the mean.

observed. The ability of $\mathrm{CN}^{-}$to inhibit nitrogenase depended on both the $\mathrm{dO}_{2}$ and the intensity of illumination. Below $80 \mu \mathrm{M}-\mathrm{O}_{2}$ and at light intensities below $2.5 \mathrm{klx}, \mathrm{CN}^{-}$completely inhibited nitrogenase activity of a culture which had optimum activity at $25 \mu \mathrm{M}-\mathrm{O}_{2}$. However, above $80 \mu \mathrm{M}-\mathrm{O}_{2}$ and at light intensities above $2.5 \mathrm{klx}$, a low rate of $\mathrm{CN}$-insensitive $\mathrm{C}_{2} \mathrm{H}_{2}$ reduction $\left.\left[0.08 \mathrm{nmol}(\mathrm{mg} \text { protein })^{-1} \mathrm{~min}^{-1}\right)\right]$ occurred, which was not inhibited by $10 \mu \mathrm{M}-\mathrm{DCMU}$.

\section{Effect of $\mathrm{dO}_{2}$ on the $\mathrm{ADP} / \mathrm{ATP}$ ratio}

$A D P / A T P$ ratio in the dark. Under anaerobic conditions in the dark, where ATP can be generated only by substrate-level phosphorylation, nitrogenase activity was not detected and the ADP/ATP ratio of suspensions of Gloeothece was $0 \cdot 47 \pm 0 \cdot 1$ (SD). When suspensions were maintained at a positive $\mathrm{dO}_{2}$ the ratio initially decreased rapidly with increasing $\mathrm{dO}_{2}$, followed 
by a more gradual decrease at higher dO. (Fig. 6). Comparison of Fig. 4 with Fig. 6 indicates that both high and low affinity $\mathrm{O}_{2}$-uptake systems couple to ATP production. However, the major change in the ADP/ATP ratio correlates with the range of $\mathrm{dO}_{2}$ where the activity of the high affinity system predominates, and where nitrogenase activity shows the most marked dependence on $\mathrm{dO}_{2}$ (Fig. $1 a, b$ ). The $\mathrm{K} . \mathrm{CN}$-insensitive $\mathrm{O}_{2}$-uptake system, which does not support nitrogenase activity, also does not couple effectively to ATP synthesis since the $\mathrm{ADP} / \mathrm{ATP}$ ratio in the dark increased from $0.18 \pm 0.05$ (SD) to $2.0 \pm 0.21$ (SD) after addition of $2 \cdot 5 \mathrm{mM}-\mathrm{KCN}$.

$A D P / A T P$ ratio in the light. In the light $1 \mathrm{klx})$ and in the absence of added $\mathrm{O}_{2}$, the ADP/ATP ratio was 0.2 (Fig. 6). The ratio showed a marginal increase at the lowest positive $\mathrm{dO}_{2}$ imposed, but thereafter remained constant with increasing $\mathrm{dO}_{2}$. The data of Fig. 6 are directly comparable with the effect of $\mathrm{dO}_{2}$ on nitrogenase activity (Fig. $1 b$ ), since the samples analysed for ADP/ATP ratio were taken from the culture on which activity measurements were made. It is clear that, in the light, changes in nitrogenase activity do not correlate with changes in the ADP/ATP ratio.

In the presence of $10 \mu \mathrm{M}-\mathrm{DCMU}$, at $11 \mu \mathrm{M}-\mathrm{O}_{2}$ and under saturating light, nitrogenase activity was stimulated twofold compared with the rate in the dark, and the ADP/ATP ratio decreased from $0.26 \pm 0.05$ (SD) to $0.14 \pm 0.03(\mathrm{SD})$.

\section{I)ISCUSSION}

With few exceptions (Hochman \& Burris, 1981; Post et al., 1983; Jensen \& Cox, 1983; Klugkist \& Haaker, 1984) studies of the effects of $\mathrm{O}_{2}$ on $\mathrm{N}_{2}$-fixation in vivo have used either different $\mathrm{pO}_{2}$ or varied shaking rates to alter the $\mathrm{dO}_{2}$. With heterotrophic organisms the $\mathrm{dO}_{2}$ is dependent both on the respiratory rate and on the solution rate of $\mathrm{O}_{2}$. In the case of organisms which photoevolve $\mathrm{O}_{2}$ the actual $\mathrm{dO}_{2}$ is even more uncertain. In our experiments, different $\mathrm{dO}_{2}$ were imposed by varying the composition of the gas phase in an apparatus which allowed nitrogenase activity and $\mathrm{dO}_{2}$ to be measured simultaneously.

Nitrogenase activity plotted against $\mathrm{dO}_{2}$ resulted in a bell-shaped curve characteristic of that of all aerobic diazotrophs. In the dark no ictivity was observed under anaerobic conditions, but it increased rapidly as the external $\mathrm{dO}_{2}$ was increased to $10 \mu \mathrm{M}-\mathrm{O}_{2}$. The optimum $\mathrm{dO}_{2}$ was the same in the light and in the dark. This general pattern is similar to that reported by Gallon \& Hamadi (1984) for Gloeothece sp. ATCC 27152, but differs in that Gallon \& Hamadi (1984) observed a rate under anaerobic conditions in the dark which was approximately $60 \%$ of the maximum. This apparent difference most probably resides in the incomplete removal of $\mathrm{O}_{2}$ in the earlier experiments since we have subsequently found an $\mathrm{O}_{2}$ requirement for nitrogenase activity in Gloeothece ATCC 27152. This emphasizes the importance of the measurement of $\mathrm{dO}_{2}$ in cultures of organisms, such as Gloeothece, which have a high affinity $\mathrm{O}_{2}$-uptake system that can couple to nitrogenase.

In both strains of Gloeothece activity is Inore susceptible to inhibition by supraoptimal $\mathrm{dO}_{2}$ in the dark than in the light but strain ATCC 27152 was more $\mathrm{O}_{2}$-tolerant since activity was still detected in the light and in the dark at a $\mathrm{pO}_{2}$ of $0.7 \mathrm{~atm}$ (Gallon \& Hamadi, 1984). Since these strains originate from the same isolate this difference may result from the adventitious selection of a variant during their independent maintenance. In agreement with this hypothesis, strain ATCC 27152, unlike PCC 6909 (Kallas $e t$ al., 1983), is capable of growth and $\mathrm{N}_{2}$-fixation at light intensities of $2.5 \mathrm{klx}$.

In the range of $\mathrm{dO}_{2}$ over which nitrogenase activity was inhibited, the time course of $\mathrm{C}_{2} \mathrm{H}_{2}$ reduction was linear, indicating that the inhibition was not due to inactivation of nitrogenase by $\mathrm{O}_{2}$, but more probably to oxidation of the electron donor to nitrogenase. The optimum $\mathrm{dO}_{2}$ of $80 \mu \mathrm{M}$ supporting maximum nitrogenase activity, and the $0.1 \mathrm{~atm} \mathrm{pO}_{2}$ reported by Gallon \& Hamadi (1984), are both higher than that of most aerobic diazotrophs, where typical values range from $1 \mu \mathrm{M}$ for cowpea Rhizobium strain $32 \mathrm{H} 1$ to $20 \mu \mathrm{M}$ for Azotobacter chroococcum (see Robson \& Postgate, 1980). Nitrogenase astivity in other non-heterocystous cyanobacteria can 
also tolerate high $\mathrm{dO}_{2}$ values since light-limited continuous cultures of Plectonema boryanum were established growing on $\mathrm{N}_{2}$ at $40 \mu \mathrm{M}-\mathrm{O}_{2}$ (Pearson \& Howsley, 1980).

The expression of aerobic nitrogenase activity by Gloeothece is not a consequence of respiration decreasing the $\mathrm{dO}_{2}$ to very low levels. The effective coupling of the high affinity $\mathrm{O}_{2}$ uptake system to both ATP synthesis and nitrogenase activity also suggests that protection of nitrogenase from inactivation by $\mathrm{O}_{2}$ does not involve an $\mathrm{O}_{2}$ diffusion barrier, as is observed in the heterocystous cyanobacterium Anabaena variabilis (Jensen \& Cox, 1983) and in Frankia sp. (Murry et al., 1984). Thus, the extensive extracellular slime capsule of Gloeothece does not appear to act as a diffusion barrier. This is in agreement with the observations that nitrogenase activity of a capsuleless mutant of Gloeothece is no more sensitive to $\mathrm{O}_{2}$ than the parental strain (Kallas et al., 1983), and that activity of strains which overproduce slime is as sensitive to $\mathrm{O}_{2}$ as the wildtype (J. R. Gallon, unpublished observation).

The high affinity $\mathrm{O}_{2}$-uptake system of Gloeothece $\left(K_{\mathrm{m}} 1 \mu \mathrm{M}\right)$ is coupled to nitrogenase activity and ATP synthesis, since at $6 \mu \mathrm{M}-\mathrm{O}_{2}$ nitrogenase activity was approximately $90 \%$ of that at the optimum $\mathrm{dO}_{2}$ and the ADP/ATP ratio was $140 \%$ of the minimum value at saturating $\mathrm{dO}_{2}$. This $\mathrm{O}_{2}$-uptake system would be effectively saturated at the optimum $\mathrm{dO}_{2}$ of $25 \mu \mathrm{M}$, a value well below that of air-saturated medium. Natural populations of Gloeothece, often found as colonies on limestone (Whitton \& Sinclair, 1975), would therefore have the potential for $\mathrm{N}_{2}$-fixation throughout the colony where a gradient of $\mathrm{dO}_{2}$ might be expected to exist.

In the dark, reductant for nitrogenase activity arises from endogenous carbon reserves (Mullineaux et al., 1980) and ATP from $\mathrm{O}_{2}$-dependent respiration. At low $\mathrm{dO}_{2}$, where the ADP/ATP ratio showed a marked decrease with increasing $\mathrm{dO}_{2}$, nitrogenase activity increased with the ADP/ATP ratio, whilst addition of $\mathrm{KCN}(2.5 \mathrm{~mm})$ increased the ADP/ATP ratio from 0.18 to 2 and completely inhibited nitrogenase activity. Total inhibition by $\mathrm{KCN}$ was also observed at moderate levels of illumination and $\mathrm{dO}_{2}$, indicating that respiration provided ATP for nitrogenase activity even in the light. The similarity of the dependence of nitrogenase activity on $\mathrm{dO}_{2}$ in the light and in the dark supports this view. Furthermore, when cultures were maintained at a fixed $\mathrm{dO}_{2}$, the rate of $\mathrm{C}_{2} \mathrm{H}_{2}$ reduction was independent of the level of illumination from darkness to $2 \mathrm{klx}$ regardless of the cell density.

The independence of nitrogenase activity from illumination differs from earlier reports where increased rates were observed in the light (see Gallon, 1980). However, both light intensity and the prevailing $\mathrm{dO}_{2}$ (in relation to the optimal $\mathrm{dO}_{2}$ of the culture) are critical parameters in determining the effect of illumination. For example, under anaerobic conditions, nitrogenase activity was stimulated by light which could well be a consequence of an increased intracellular $\mathrm{dO}_{2}$ rather than a direct effect of increased photophosphorylation. However, under saturating light intensities $(\sim 30 \mathrm{klx})$ in the presence of DCMU the observed twofold stimulation of nitrogenase activity is consistent with the view that activity is normally limited by the availability of ATP, since the generation of reducing equivalents derived from photosynthesis is inhibited under these conditions.

Our broad conclusion is that respiration provides ATP for $\mathrm{N}_{2}$-fixation by Gloeothece sp. PCC 6909 both in the dark and in the light. In addition, its ability to conduct aerobic $\mathrm{N}_{2}$ fixation does not involve respiratory protection of the kind observed in Azotobacter, where high rates of respiration decrease the ambient $\mathrm{dO}_{2}$ to low levels (see Robson \& Postgate, 1980).

We gratefully acknowledge the provision of an SERC CASE award to P.S.M. and the award of Scientific Investigation Grants from the Royal Society to A.E.C. and J.R. G. We also thank Dr D. J. Lowe for assistance with computing and Professor J. R. Postgate for constructive criticism of the manuscript.

\section{REFERENCES}

CORNISH-BOWDEN, A. (1979). Fundamentals of Enzyme Kinetics. London: Butterworth.

Gallon, J. R. (1980). Nitrogen fixation by photoautotrophs. In Nitrogen Fixation, pp. 197-238. Edited by W. D. P. Stewart \& J. R. Gallon. London: Academic Press.
Gallon, J. R. \& Hamadi, A. F. (1984). Studies on the effects of oxygen on acetylene reduction (nitrogen fixation) in Gloeothece sp. ATCC 27152. Journal of General Microbiology 130, 495-503.

Gallon, J. R., larue, T. A. \& Kurz, W. G. W. (1974). Photosynthesis and nitrogenase activity in 
the blue-green alga Gloeocapsa. Canadian Journil of Microbiology 20, 1633-1637.

Gallon, J. R., Ul-Haque, M. I. \& Chaplin, A. E. (1978). Fluoroacetate metabolism in Gloeocapsa sp. LB795 and its relationship to acetylene reduction (nitrogen fixation). Journal of General Microbio'ogy 106, 329-336.

HaAker, H., DE KoK, A. \& Veeger, C. (1974). Regulation of dinitrogen fixation in intact Azotobacter vinelandii. Biochimica et biophysica acta 357, 344-357.

Hochman, A. \& BurRis, R. H. (1981). Effect of oxygen on acetylene reduction by photosynthetic bacteria. Journal of Bacteriology 147, 492-499.

JENSEN, B. B. \& Cox, R. P. (1983). Effect of oxygen concentrations on dark nitrogen fixation and respiration in cyanobacteria. Archives of Microbiology 135, 287-292.

Kallas, T., RippKa, R., Coursin, T., Rebiere, M -C., de Marsac, N. T. \& Cohen-Bazire, G. (1983). Aerobic nitrogen fixation by nonheterocystous cyanobacteria. In Photosynthetic Prokaryotes, pp. 281-302. Edited by G. C. Papageorgiou \& L. Packer. Amsterdam: Elsevier.

KLUGKIST, J. \& HaAKER, H. (1984). Inhibition of nitrogenase activity by ammonium chloride in Azotobacter vinelandii. Journal of Bacteriology 157 , 148-151.
Mullineaux, P. M., Chaplin, A. E. \& Gallon, J. R. (1980). Effects of a light to dark transition on carbon reserves, nitrogen fixation and ATP concentrations in cultures of Gloeocapsa (Gloeothece) sp. 1430/3. Journal of General Microbiology 120, 227-232.

Mullineaux, P. M., Gallon, J. R. \& Chaplin, A. E (1981). Acetylene reduction (nitrogen fixation) by cyanobacteria grown under alternating light-dark cycles. FEMS Microbiology Letters 10, 245-247.

Murry, M. A., Fontaine, M. S. \& Tuepkema, J. D. (1984). Oxygen protection of nitrogenase in Frankia sp. HFPArI3. Archives of Microbiology 139, 162-166.

Pearson, H. W. \& Howsley, R. (1980). Concomitant photoautotrophic growth and nitrogenase activity by cyanobacterium Plectonema boryanum in continuous culture. Nature, London 288, 263-265.

Post, E., Kleiner, D. \& Oelze, J. (1983). Whole cell respiration and nitrogenase activities in Azotobacter vinelandii growing in oxygen controlled continuous culture. Archives of Microbiology 134, 68-72.

Robson, R. L. \& Postgate, J. R. (1980). Oxygen and hydrogen in biological nitrogen fixation. Annual Review of Microbiology 34, 183-207.

StewarT, W. D. P. (1980). Some aspects of structure and function in $\mathrm{N}_{2}$-fixing cyanobacteria. Annual Review of Microbiology 34, 497-536.

Whitton, B. A. \& SinClair, C. (1975). Ecology of bluegreen algae. Science Progress 62, 429-446. 